\title{
Engagement in international entrepreneurship: interactive effects of resource-based factors and institutional environments
}

\author{
Tianchen Li®D
}

Correspondence: t.x.li@mdx.ac.uk Middlesex Business School,

Middlesex University, The Burroughs, Hendon, London NW4 4BT, UK

\begin{abstract}
Purpose: Integrating the resource-based view and institutional approach, this study aims to examine how resource-based factors and formal and informal institutional context interact in influencing the international engagement.

Design/methodology/approach: Based on the data from the Global Entrepreneurship Monitor surveys, this paper performs a multilevel estimation approach in which cross-level (random effects) moderation analysis is applied.

Findings: This paper offers new insights into the internationalisation by ascertaining the primary role of resource-based factors in influencing internationalisation. In addition, it reveals the differential contingent values of formal and informal institutions in regard to the relationship between resource-based characteristics and internationalisation.

Practical implications: The research findings reveal the importance of the countryspecific institutional system to drive early stage entrepreneurs' intention to go international. In addition, the significant impacts of formal and informal institutions call upon policy-makers to improve institutional environments (e.g. government policies, governmental programmes, entrepreneurial finance, market openness, commercial and professional infrastructure, intellectual property rights, etc.).
\end{abstract}

Research originality: This research indicates that the degree of internationalization increases when entrepreneurs possess the necessary resources and under suitable formal and informal institutional environments.

Keywords: Internationalisation, Resource-based view, Institutional theory, Global Entrepreneurship Monitor

\section{Introduction}

International market expansion is a process fraught with difficulty for entrepreneurs. Despite a rising body of research documenting the effect of international expansion (e.g. Autio, 2005; Coviello \& McAuley,1999; Fabian et al., 2009; Ireland \& Webb, 2009; McDougall et al., 1994; Tracey \& Phillips, 2011), much less emphasis has been paid to the determining factors of firms going international (Zahra et al., 2005; Zander, McDougall-Covin, \& Rose, 2015). As a micro-level antecedent, the resource-based view

(c) The Author(s). 2019 Open Access This article is distributed under the terms of the Creative Commons Attribution 4.0 International License (http://creativecommons.org/licenses/by/4.0/), which permits unrestricted use, distribution, and reproduction in any medium, provided you give appropriate credit to the original author(s) and the source, provide a link to the Creative Commons license, and indicate if changes were made. 
(RBV) appears to play an especially significant role in entrepreneurship (Lim et al., 2016). In particular, the RBV conceives firms' resources as the primary determinants of entrepreneurial activity (Bloodgood et al., 1996; Piercy et al., 1998), in the sense that enterprises that exploit a unique bundle of valuable, rare, imperfectly imitable and substitutable resources have more motives to engage in entrepreneurial activities. While the effects of RBV on entrepreneurship have been acknowledged in the literature, how resource-based factors affect international market expansion deserves more research in the international business domain. The first objective of this study is to address this gap by looking at how resource-based factors are related to the degree of internationalisation.

Furthermore, this paper applies an institutional perspective to clarify the relationship between resource-based factors and the degree of internationalisation across countries. Randolph-Seng et al. (2015) emphasised the need for multilevel analysis in entrepreneurial behaviour research. This paper argues that the cross-level integration needs to be performed in order to demonstrate additional detail about how external institutions can play a role in influencing entrepreneurs' act on their specific resources. The impacts of institutions in shaping firms' internationalisation behaviour are not new in the broad international business area. Nonetheless, how entrepreneurs' home formal and informal institutions modify entrepreneurs' resource-based factors in affecting internationalization remains under-researched. This is a significant gap because firms going international are a context-dependent decision in which institutional environments shape and regulate the extent to which individuals can utilise their specific resources (McMullen \& Shepherd, 2006). Therefore, the second objective of this paper is to assess how the macro-level home country formal and informal institutions might promote or inhibit the resource-based aspects and internationalisation relationships.

This paper makes a number of important contributions to the existing literature on both international business (IB) and international entrepreneurship (IE). First, it takes an important step forward beyond the existing research by developing an empirical model based on the resource-based view. This paper provides simultaneous considerations of motivational factors by looking at how individuals' resources in terms of human capital and financial capital contribute to international entrepreneurship. Second, this paper investigates the contingent role of institutional dimensions in regulating the resource-based factors and internationalisation relationship. It extends the knowledge in that it studies not only the direct impacts of the contextual contingency of homecountries' institutions at the macro-level but also the indirect impacts on RBV antecedents at the micro-level. Third, extant research applies either a micro- or macrooriented approach to studying internationalisation, rarely integrating the two, which may contribute to explain the inconsistent findings (Dimov, 2007; Shepherd, 2010). A multilevel analysis is therefore needed in order to reveal how institutions can function properly as expected to encourage entrepreneurs' specific resources to be leveraged into international entrepreneurship (Hitt et al., 2007; Kiss et al., 2012; Shepherd, 2010). Therefore, this study adds to the knowledge of how the application of institutional approaches to the well-established resource-based theories enables a fine-grained investigation of internationalisation. While both theories are well acclaimed, their overt foci tend to oversee broader linkages between resource-based characteristics and contextual influences in entrepreneurship (Welter, 2011). This study complements RBV by 
incorporating formal and informal institutional antecedents in explaining the degree of internationalisation and contributing to the empirical forefront of the RBV theory.

Below, this paper first uses the resource-based view to conceptualise the link between entrepreneurs' resources and their international entrepreneurial activities. In the "Formal and informal institutions" section, it discusses how institutional dimensions (i.e. formal and informal institutions) might interact with entrepreneurs' resources in influencing their early internationalisation. "Data and method" section discusses the method and sample. The "Results and discussion" section shows the empirical results. "Conclusions" section concludes with some discussions on the implications for theory and practice.

\section{Literature review and hypothesis development}

\section{The resource-based view: international entrepreneurship nexus}

The RBV has in recent years been used as a primary paradigm that is directing the inquiry into antecedents of entrepreneurship (Hitt et al., 2006; Tseng et al., 2007; Westhead et al., 2001). The empirical content of the RBV suggests that there is a positive association between an array of entrepreneurial, technological and organisational parameters and businesses going international (Brouthers et al., 2015; Filatotchev et al., 2008; Knight \& Cavusgil, 2004). While extant entrepreneurship literature typically adopts a macro-level approach, many of the primary resources needed for entrepreneurial activities, including human and financial capital, are grounded on individuals (Autio \& Acs, 2010). Hence, an important issue is the extent to which micro-level resource-based factors influence international entrepreneurship. In this paper, it focuses on human capital and financial capital as two fundamental resources. It responds to a key question of development economics regarding how human and financial resources can be related to entrepreneurial activities (Dias \& McDermott, 2006; King \& Levine, 1993; Murphy et al., 1991). Information regarding global business opportunities is not uniformly available (Hayek, 1945) and therefore entrepreneurs' idiosyncratic knowledge base generates a knowledge corridor, which in turn, promotes the discovery, exploration and assessment of opportunities in global markets (McMullen \& Shepherd, 2006; Shane, 2000). The entrepreneurship literature suggests that human capital makes entrepreneurs more "outward looking", and therefore, increases their ability to recognise and capture business opportunities (e.g. Evald et al., 2011; Zahra et al., 2005). These abilities enable entrepreneurs to have a higher intention to explore international markets. Moreover, financial resources play another instrumental role in the entrepreneurial process (Autio \& Acs, 2010). In line with Frese and Gielnik (2014), entrepreneurs might be more motivated to engage in exploring global opportunities when they have more resources to act on them. Likewise, Arenius and De Clercq (2005) found that the levers for social stratification can be caused by household income, which in turn, increases access to high-quality information about business opportunities. Taking the above arguments together, it proposes that:

Hypothesis 1a: Human resources are positively related to the degree of internationalisation.

Hypothesis 1b: Financial resources are positively related to the degree of internationalisation. 


\section{Formal and informal institutions}

This section extends the theoretical discussion to assess how resource-based variables interact with home country formal and informal institutions in influencing firms' internationalisation.

In existing literature, entrepreneurship has been enriched by four streams: economic, psychological, organisational and institutional (Verheul et al., 2002; Veciana, 1999). Following these approaches, most studies have taken institutional theory as the grounding for explaining the differences in entrepreneurial activity across countries (e.g. Urbanoand Alvarez, 2014; Dau and Cuerzo-Cazurra, 2014). The institutional environments not only directly affect the level of entrepreneurship, but also indirectly influence entrepreneurship initiatives (Bruton et al. 2010; Contractor, Kumar, \& Kundu, 2007; Scott, 1995). Institutions are defined broadly and differently in the literature. Veblen (1914) stated that institutions can be regarded as settled habits of thought applied to the generality of individuals, including usage, customs and principles of right and propriety. Hamilton (1932) defined institutions as an approach of thought or action of performance, embedded in the habits of the customs of a group. Other authors have argued that institutions are the social regulations that function as opportunities and constraints establishing human interaction (North, 1990); norms that govern individuals' relations (Parsons, 1990); and social structures that are associated with a high degree of resilience (Scott, 1995). There are two broad branches in the development of institutional theories, with one being from sociology and organisational theory and the other deriving from political science and economics (Ahlstrom \& Bruton, 2001; DiMaggio \& Powell, 1991). The first branch suggests that cognitive schemas, social norms and shared attitudes act as the key drivers of human behaviour (Ahlstrom \& Bruton, 2002). The political science and economics branch suggests that formal control, procedures and rules are the primary drivers of human interaction (North, 1990, 2005). North (1990) stated that institutions can be formal (regulations, contracts, constitutions, etc.) or informal (attitudes, norms, or the culture and values of a society). Institutions are regarded as structures, from regulations and rules to the culture, traditions and customs (Szyliowicz \& Galvin, 2010). These structures form the logic manipulating economic decision-making and behaviour (Yeung, 2002). Entrepreneurship, like other economic activities, has been regarded to be informed by both formal and informal institutions (Muralidharan \& Pathak, 2016). According to (Etemad 2004), home institutions are described as the primary push factors for international entrepreneurship. Nevertheless, research on the effects of country environments has placed more emphasis on the specific nature of institutions per se, and not on the interaction between the institutional and individual-level factors. This research argues that the explanatory power of resource-based aspects of international market expansion is modified by the strength of the local institutional forces. The social systems of a firm's institutional environment interact with RBV characteristics in affecting internationalisation.

\section{Formal institutions}

Formal institutions are defined as rules, such as policy, constitutions, contracts, laws, property rights and economy-related rules (North, 1990). The seminal work from Khanna and Palepu (1997) suggests that home country institutions cannot be simply 
viewed as homogeneous and entrepreneurs need to be aware that formal institutions such as policies, capital infrastructure and product market regulations regulate how they develop their activities. In previous studies, formal institutions have been viewed relevant in the research of how institutional context influence business performance (Chacar \& Vissa, 2005; McGahan and Victer, 2010) and internationalisation (Zhang et al., 2016). These institutions appear to exert an important impact on firms' competitiveness and local economic development (Acemoglu and Johnson, 2005). Such home country institutions are considered important country-level factors that are capable of forming domestic businesses' capacity to compete in the global market (Mudambi \& Navarra, 2002).

Formal institutions lay out the ground rules for business operations, reflecting the regulations and laws of a country and the extent to which they are effectively monitored and executed. They affect the development of entrepreneurship through different policy measures (Bruton et al., 2010; Lim et al., 2010). Well-developed institutional foundations in which institutional voids are less permeated lead to the more efficient functioning of markets, thereby reducing transaction costs (North, 1990); institutional foundations increase the availability of requisite resources, and therefore, influence the social desirability of going international (Spence, 1973). Moreover, in countries where institutional environments are less deficient in terms of law enforcement, legal protection for property rights, market functioning and market infrastructure, entrepreneurs may anticipate fewer obstacles or impediments and uncertainty with regard internationalising (Troilo, 2011). On the other hand, formal institutions with excessive bureaucracy, failure to deliver legal commitments and high tax burdens increase the difficulty for entrepreneurs to leverage resources towards international expansion, as they obscure the possible pathways by which human and financial resources can create positive outcomes from international expansion. Therefore, it is argued that:

Hypothesis 2: Formal institutions positively moderate the relationship between resource-based factors and the degree of internationalisation.

\section{Informal institutions}

Informal institutions refer to social expectations in regard to appropriate actions in line with dominant norms and practices, and shared understandings based on cultural values in a given society (Bruton et al., 2010; Javidan et al., 2006; Stephan et al., 2014). Social psychologists suggest that one of the primary perceptions that can foresee the intention to pursue a business opportunity is the perceived support of informal institutions including social norms and cultural values, which act as the grounding rules to the member of society (Carsurd \& Krueger, 1995; Locke \& Baum, 2007). Entrepreneurs are encouraged to internationalise not only in the light of formal conditions but also by the conception that constitutes the social frames and the reality reflecting the way of information interpretation. For instance, according to Ajzen (1991), entrepreneurs' cognitive self-regulation is a key aspect of human behaviour that can safeguard and amplify the role of resources. Likewise, Bruton et al. (2008) argued that the institutional environment affects the process of receiving legitimacy, and therefore, secure firms' resources. Entrepreneurs tend to emulate the performance of their peers by early 
internationalisation. In contrast, individuals might be discouraged from performing their human and financial resources to entrepreneurial activities in both domestic and international markets in which the prevailing norms and values associate entrepreneurial activities with profiteering or parasitism (Manolova et al., 2008). Therefore, it proposes that a more favourable informal institutional environment can strengthen the impacts of resource-based factors on international expansion.

Hypothesis 3: Informal institutions positively moderate the relationship between resource-based factors and the degree of internationalisation.

\section{Data and method}

Data

The proposed hypotheses were tested based on a multilevel construct including individual and country-level variables. The data were collected from the 2014 Global Entrepreneurship Monitor-Adult Population Survey (GEM-APS) and Global Entrepreneurship Monitor- National Expert Survey (GEM-NES). A geographically stratified sampling procedure was employed in GEM surveys. It defines early stage entrepreneurs as people doing business in the first three months and firm owners involved in running a business up to 3.5 years. This paper involved early stage entrepreneurs from each of the 70 countries and the final sample consists of 201,841 respondents.

\section{Dependent variable}

Internationalisation: Following prior studies (e.g. Evald et al., 2011; Muralidharan \& Pathak, 2016; Li, 2018), the degree of internationalisation was captured by the portion of foreign sales among total sales. The data asked the respondents to identify the portion of their customers living outside. The responses were classified into four categories.

\section{Independent variable}

Resource-based variables: Prior research has measured human capital resources by questioning subjects regarding entrepreneur's education level (Lim et al., 2016). Following this approach, the entrepreneurs were required to reflect their highest qualification into a four-category variable: "primary or below", "secondary", "post-secondary" and "graduate experience". Following prior research (e.g. Autio \& Acs, 2010; Minniti \& Nardone, 2007; Reynolds et al., 2005), the financial capital was measured using the response to entrepreneur's income tier $(1=$ lower income tier, $2=$ middle income tier and 3 = upper income tier).

\section{Country-level predictors}

Institutional dimensions: Adopting Alvarez, Urbano, Coduras and Ruiz-Navarro's (2011) frame, this paper used eight items to measure the formal institution context at the country level, referring to government policies, governmental programmes, entrepreneurial finance, $\mathrm{R} \% \mathrm{D}$ transfer, commercial and professional infrastructure, market openness, intellectual property rights and physical infrastructure. Consistent with the conceptualisation of informal institution from Alvarez et al. (2011), informal institution 
was reflected by cultural and social norms, opportunities to entrepreneurial start-up, abilities, entrepreneurship social image and interest in innovation. In order to aggregate these items into indices, a principal component analysis was performed. Table 1 details the results of our analysis using Varimax rotation with Kaiser normalisation. The rotated factor matrix created a two-factor solution, with acceptable results $(\mathrm{KMO}=$ $0.877, p<0.001)$. The standardised loading values are greater than the threshold of 0.5 and average variance extracted is above the recommended threshold of 0.5 , which indicate an adequate convergence. In addition, the Cronbach's alpha and composite reliability are higher than the benchmark respectively. Therefore, it concludes that the aggregated indices have good reliability and validity.

A wealth of other factors were controlled. De Carolis and Saparito (2006) suggested male has a greater propensity of going international than female. This research therefore controlled for gender. Age (Arenius \& Minniti, 2005; Westhead, 1995) appears to be associated with entrepreneurial firms' internationalisation. It thus controlled entrepreneurs' age. According to Barkema and Vermeulen (1998), large businesses have possessed more resources in international expansion; it therefore controlled firm size. In order to control for industry effects on internationalization, four categories of industrial sectors were defined in this research (i.e. extractive industry, transforming industry, business services and consumer-oriented industry). In the analysis, extractive industry will be taken as the reference category.

Table 1 Factor loadings on institutional constructs

\begin{tabular}{|c|c|c|c|c|}
\hline Construct & Item & $\begin{array}{l}\text { Cronbach's } \\
\text { alpha }\end{array}$ & $\begin{array}{l}\text { Composite } \\
\text { Reliability }\end{array}$ & $\begin{array}{l}\text { Factor } \\
\text { loading }\end{array}$ \\
\hline Formal institutions & & 0.897 & 0.926 & \\
\hline Finance & Financial environment related to entrepreneurship & & & 0.751 \\
\hline Policies & Government concrete policies, priority and support & & & 0.635 \\
\hline Government & Government programmes & & & 0.794 \\
\hline$R \& D$ & R\&D level of transference & & & 0.721 \\
\hline $\begin{array}{l}\text { Infrastructure } \\
\text { access }\end{array}$ & Professional and commercial infrastructure access & & & 0.765 \\
\hline $\begin{array}{l}\text { Market } \\
\text { openness }\end{array}$ & Internal market dynamics/internal market burdens & & & 0.798 \\
\hline $\begin{array}{l}\text { Physical } \\
\text { infrastructures }\end{array}$ & Physical infrastructures and services access & & & 0.757 \\
\hline $\begin{array}{l}\text { Intellectual } \\
\text { property rights }\end{array}$ & Intellectual property rights situation & & & 0.993 \\
\hline Informal institutions & & 0.875 & 0.895 & \\
\hline $\begin{array}{l}\text { Cultural and } \\
\text { social norms }\end{array}$ & Cultural, social norms and society support & & & 0.742 \\
\hline $\begin{array}{l}\text { Opportunities } \\
\text { for start-up }\end{array}$ & $\begin{array}{l}\text { Good conditions to start a business next } 6 \text { months } \\
\text { in the area the respondents live }\end{array}$ & & & 0.761 \\
\hline Abilities & Has the required knowledge/skills to start a business & & & 0.840 \\
\hline $\begin{array}{l}\text { Entrepreneur } \\
\text { social image }\end{array}$ & $\begin{array}{l}\text { People consider starting a business as a good } \\
\text { career choice }\end{array}$ & & & 0.876 \\
\hline $\begin{array}{l}\text { Interest in } \\
\text { innovation }\end{array}$ & Uses new technology & & & 0.741 \\
\hline
\end{tabular}




\section{Sample and design}

Due to the discrete and rank-ordered nature of the dependent variable, the effects of internationalisation are examined using an ordinal logit model. As this research merged individual-level variables with national-level constructs, the data were analysed based on multilevel approaches. In order to predict the role of national-level characteristics on the degree of internationalisation, this study performed random effects with unobserved country-specific intercepts and country-specific slopes, enabling the intercept and slopes to vary across countries in order to model unobserved country-level heterogeneity. The econometric model is demonstrated below:

where $\mathrm{y}_{i j}^{*}=$ latent dependent variable $i$ in country $j, \gamma_{00}=$ intercept, $\gamma_{0 n}=$ main effect coefficients of individual-level predictors and control variables, $\gamma_{n 0}=$ main effect coefficients of country-level predictors and $\gamma_{1 n}=$ main effect coefficients of cross-level interaction terms. The combination of $\left(U_{0 j}+U_{1 j} x_{i j}+U_{2 j} x_{i j}+\varepsilon_{i j}\right)$ represents a random part of the equation. $U_{0 j}$ and $U_{1 j}$ are country-level residuals, and $\varepsilon_{i j}$ represents the individuallevel residuals $x_{i j}$ represent individual-level direct effects.

\section{Results and discussion}

Table 2 lists the pairwise correlation coefficients. Variance inflation factors (VIFs) were examined as a further diagnostic test of the possibility of multicollinearity. Given that none of the VIFs factors of any of the variables in the analyses exceed 5 (Ryan, 1997), this suggests that multicollinearity is of minimal concern.

In order to demonstrate the between-country variance, this paper hence conducted a chi-square test. This test implies significant between-group variance within the data, with $X^{2}(207)=6.746$ E3 $(p<0.000)$. The analytical results are reported in Tables 3 and 4 . All of the control variables were included in model 1 . The results are generally consistent with existing empirical evidence. Males are found to be more likely to internationalise their own businesses than females. In particular, male entrepreneurs are around 51.7\% more likely to do business internationally than females in odds ratio. Additionally, business size is found to positively affect the probability of engaging in international expansion. In particular, when there is a one unit increase in business scale, the degree of internationalisation can increase by $41.3 \%$ in odds on average. In which industry the new business is trading also matters. Entrepreneurs in the business service and customeroriented industries have a higher probability of being internationalised than those from the extractive industry.

Model 2 included the main effects of resource-based predictors. Next, this paper added the first interaction term (resource-based factors * formal institutions) in model 3. Model 4 replaced this with the second hypothesised interaction term (resource-based factors * informal institutions). Model 5 incorporated both formal and informal institutions as a robustness check.

In model 2 , the result shows that human resources are significantly and positively related to internationalisation $(p<0.001)$. Financial resources appear to have a significant and positive relationship with the probability of early stage entrepreneurs engaging in international business. When there is a one unit increase in the income level, the odds ratio of entrepreneurs going international increased by a factor of $1.119(p<0.001)$. Therefore, hypotheses $1 \mathrm{a}$ and $1 \mathrm{~b}$ are supported. The interaction terms were entered from model 3 to model 5 . The 


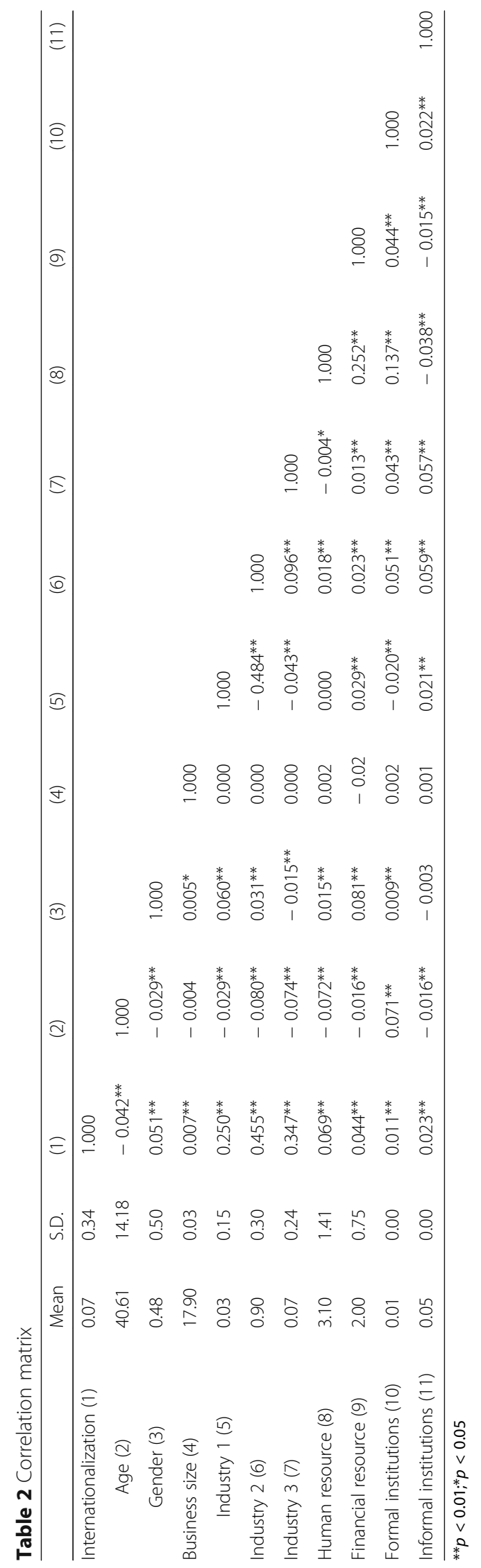




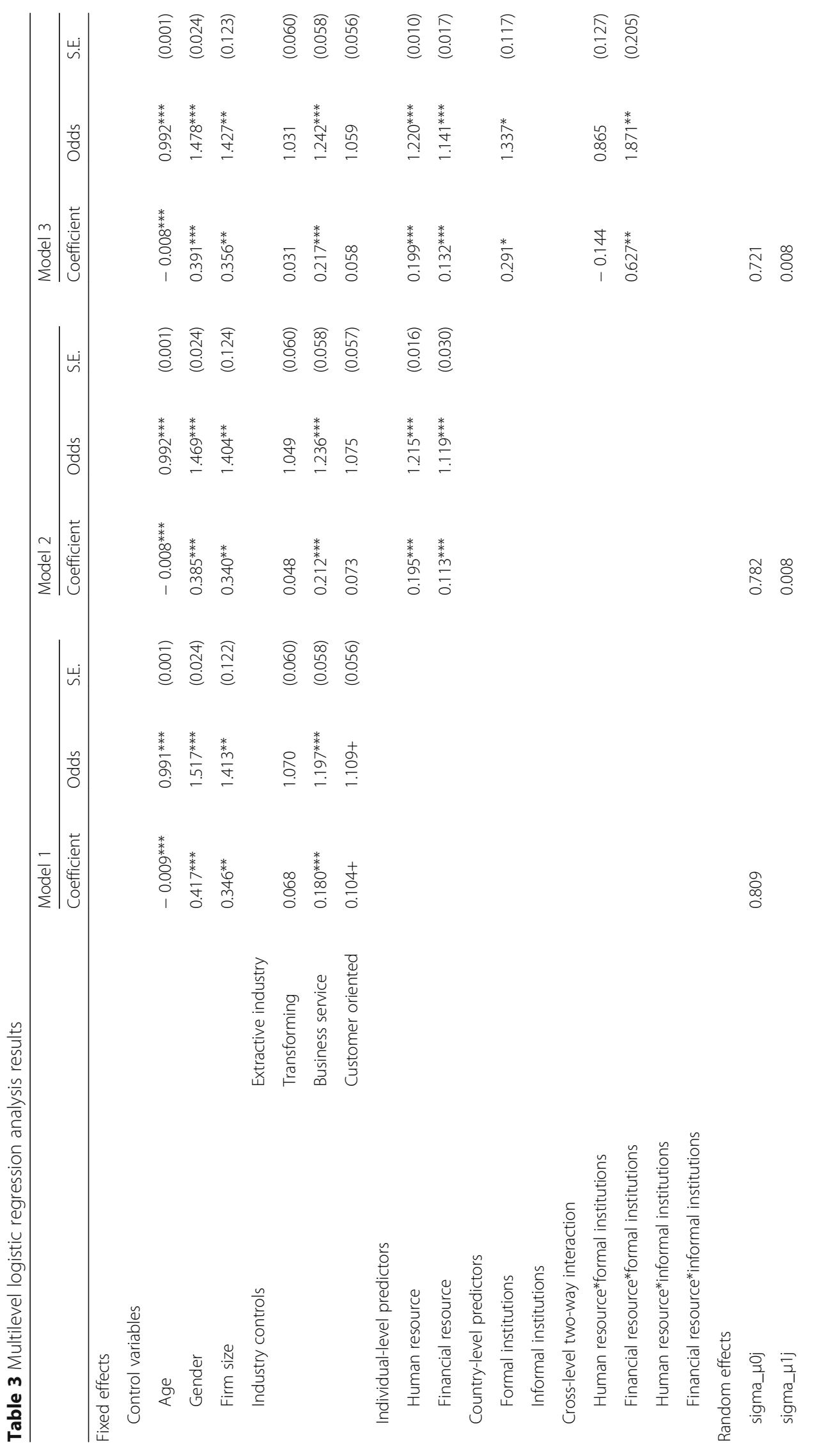




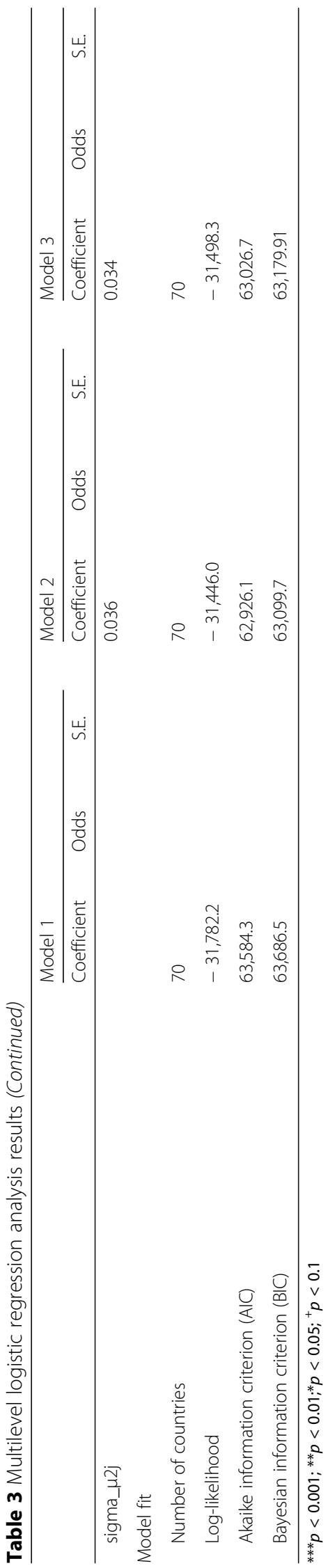


Table 4 Multilevel logistic regression analysis results

\begin{tabular}{|c|c|c|c|c|c|c|c|}
\hline & & \multicolumn{3}{|l|}{ Model 4} & \multicolumn{3}{|l|}{ Model 5} \\
\hline & & Coefficient & Odds & S.E. & Coefficient & Odds & S.E. \\
\hline \multicolumn{8}{|l|}{ Fixed effects } \\
\hline \multicolumn{8}{|l|}{ Control variables } \\
\hline Age & & $-0.008^{* * *}$ & $0.992^{* * *}$ & $(0.001)$ & $\overline{0.008 * * *}$ & $0.992^{* * *}$ & $(0.001)$ \\
\hline Gender & & $0.392^{* * *}$ & $1.479^{* * *}$ & $(0.024)$ & $0.392^{* * *}$ & $1.479^{* * *}$ & $(0.024)$ \\
\hline Firm size & & $0.360^{* *}$ & $1.433^{* *}$ & $(0.124)$ & $0.356^{* *}$ & $1.427^{* *}$ & $(0.123)$ \\
\hline \multirow[t]{4}{*}{ Industry controls } & $\begin{array}{l}\text { Extractive } \\
\text { industry }\end{array}$ & & & & & & \\
\hline & Transforming & 0.031 & 1.031 & $(0.060)$ & 0.031 & 1.031 & $(0.060)$ \\
\hline & $\begin{array}{l}\text { Business } \\
\text { service }\end{array}$ & $0.215^{* * *}$ & $1.239 * * *$ & $(0.058)$ & $0.217^{* * *}$ & $1.242^{* * *}$ & $(0.058)$ \\
\hline & $\begin{array}{l}\text { Customer } \\
\text { oriented }\end{array}$ & 0.059 & 1.060 & $(0.056)$ & 0.058 & 1.059 & $(0.056)$ \\
\hline \multicolumn{8}{|l|}{ Individual-level predictors } \\
\hline Human resource & & $0.199^{* * *}$ & $1.220^{* * *}$ & $(0.010)$ & $0.199^{* * *}$ & $1.220^{* * *}$ & $(0.010)$ \\
\hline Financial resource & & $0.128^{* * *}$ & $1.136^{* * *}$ & $(0.017)$ & $0.133^{* * *}$ & $1.142^{* * *}$ & $(0.017)$ \\
\hline \multicolumn{8}{|l|}{ Country-level predictors } \\
\hline Formal institutions & & & & & $0.294^{* *}$ & $1.341^{* *}$ & $(0.110)$ \\
\hline Informal institutions & & 0.110 & 1.116 & $(0.248)$ & 0.128 & 1.136 & $(0.243)$ \\
\hline \multicolumn{8}{|l|}{ Cross-level two-way interaction } \\
\hline $\begin{array}{l}\text { Human resource*formal } \\
\text { institutions }\end{array}$ & & & & & -0.152 & 0.858 & $(0.127)$ \\
\hline $\begin{array}{l}\text { Financial resource formal } \\
\text { institutions }\end{array}$ & & & & & $0.635^{* *}$ & $1.887^{* *}$ & $(0.205)$ \\
\hline $\begin{array}{l}\text { Human resource }{ }^{*} \text { informal } \\
\text { institutions }\end{array}$ & & $0.054^{*}$ & $1.055^{*}$ & $(0.027)$ & $0.056^{*}$ & $1.057^{*}$ & $(0.027)$ \\
\hline $\begin{array}{l}\text { Financial resource*informal } \\
\text { institutions }\end{array}$ & & -0.044 & 0.956 & $(0.043)$ & -0.049 & 0.952 & $(0.043)$ \\
\hline \multicolumn{8}{|l|}{ Random effects } \\
\hline sigma_ $\mu 0 j$ & & 0.778 & & & 0.717 & & \\
\hline sigma_ $\mu 1 j$ & & 0.008 & & & 0.007 & & \\
\hline sigma_ $\mu 2 j$ & & 0.036 & & & 0.033 & & \\
\hline \multicolumn{8}{|l|}{ Model fit } \\
\hline Number of countries & & 70 & & & 70 & & \\
\hline Log-likelihood & & $-31,502.2$ & & & $-31,495.5$ & & \\
\hline $\begin{array}{l}\text { Akaike information criterion } \\
\text { (AIC) }\end{array}$ & & $63,034.4$ & & & $63,026.9$ & & \\
\hline $\begin{array}{l}\text { Bayesian information criterion } \\
\text { (BIC) }\end{array}$ & & $63,187.7$ & & & $63,210.8$ & & \\
\hline
\end{tabular}

${ }^{* * *} p<0.001 ;{ }^{* *} p<0.01 ; * p<0.05 ;{ }^{+} p<0.1$

findings confirm the assumption that stronger institutional foundations can modify the association between resource-based factors and the degree of internationalisation. The positive relationship between financial resource and internationalisation is enhanced by $87.2 \%$ in terms of odds under stronger formal institutions, supporting hypothesis 2. In addition, this paper identifies the significant and positive moderating effect of informal institutions on the effects of human resources on the degree of internationalisation, suggesting that when 
the perceived support of informal institutions including social norms and cultural values is strong, it can strengthen the positive impacts of human resources on the extent of internationalisation; however, such an impact cannot be observed on financial resources and thus hypothesis 3 is partially supported. Figures 1 to 2 are plotted in order to visualise the indirect impacts of formal and informal institutions on resource-based factors and early internationalisation.

\section{Conclusions}

This paper reveals the impacts of human and financial resources on early internationalisation and looks at whether country-level formal and informal institutions can modify these associations. Given that the novel feature of the models is the link between the extant macro theories (i.e. formal and informal institutions) and micro-level antecedents (i.e. resource-based view), the analytical results suggest the positive effects of the RBV variables (i.e. human resource and financial resource) and find that formal and informal institutions affect these relationships differently.

\section{Theoretical implications}

This research has important contributions. First, there have been two independent developments in the extant literature that have attempted to improve our understanding of why entrepreneurial firms go international from individual (i.e. entrepreneurs) and institutional perspectives. This paper takes an important step in this direction by bridging the differences in entrepreneurs' human and financial capitals and formal and informal environments. Second, it acknowledges that entrepreneurs are not identical (Dunkelberg et al., 2013) and that they differ in their central resource constructs. In particular, this paper provides theoretical arguments as well as empirical evidence on how human and financial resources shape the degree of internationalisation. Third, the research findings complement the existing empirical studies that concentrate on the primary role of home country institutions in entrepreneurship. Formal and informal institutions have divergent implications for releasing the impacts of resource-based factors on international expansion, which brings a sense of complexity to the extant studies.

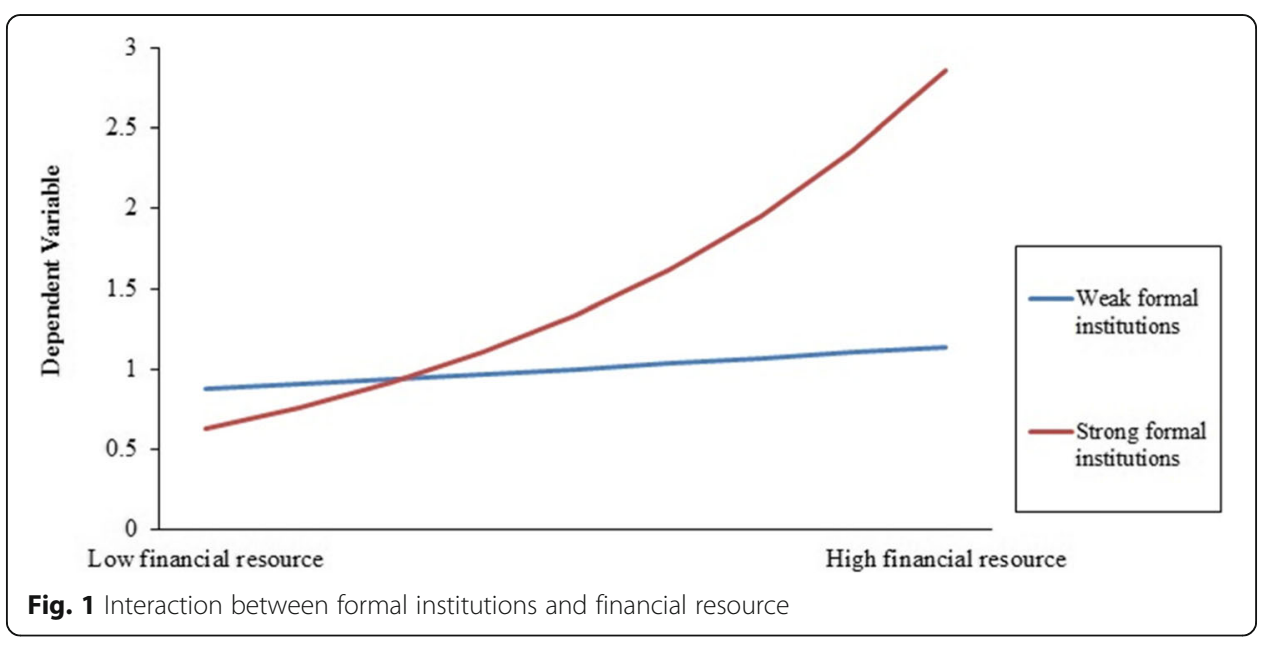




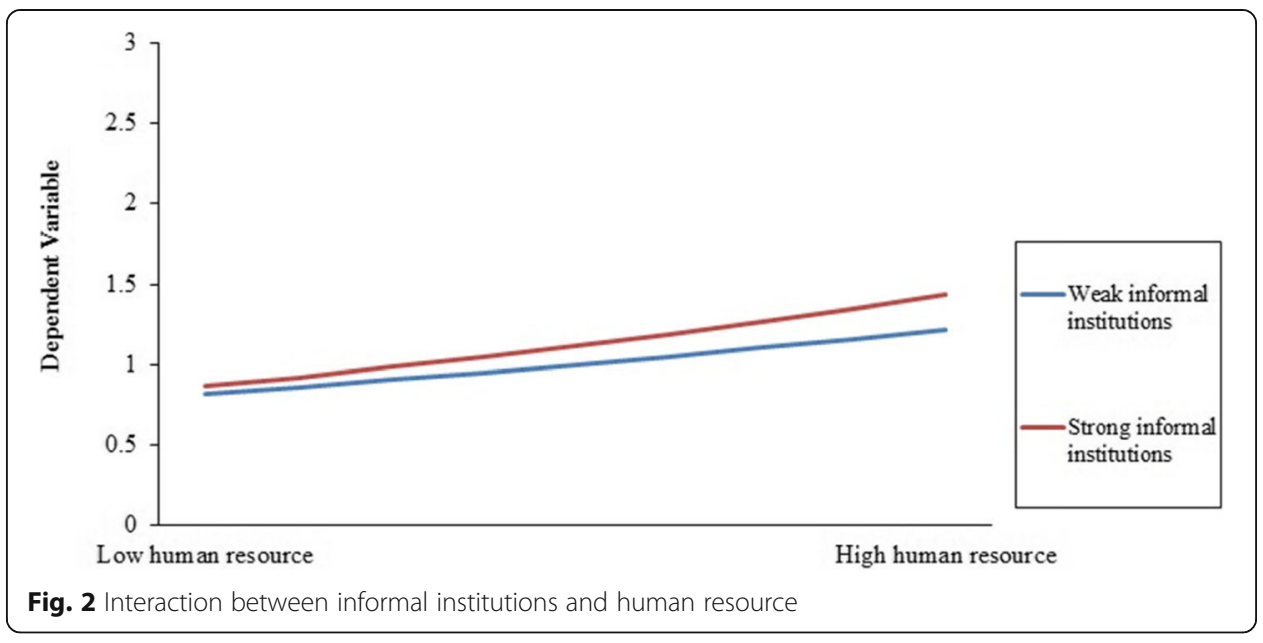

\section{Practical implications}

Although policy-makers have primarily focused on institutions in order to enhance entrepreneurial opportunities, institutional environments may be insufficient to encourage international entrepreneurship development (Stephan \& Uhlaner, 2010). The research findings bring necessary insights for business owners who need to understand the interactions between internal resources and domestic institutional factors in affecting their decision to internationalise. From a resource-based perspective, entrepreneurs should develop the appropriate organisational mechanisms and functions in order to enhance their capacity to deploy international strengths and explore opportunities in international markets. In parallel, the institutional view suggests that firms' strategies are contingent upon the external context and entrepreneurs should focus not only on developing their competitive resources but also on matching them with the context formed by the formal and informal institutional setting. Given the significant interaction effects of the home country's institutional environment in the resources-internationalisation link, governments should promote and reinforce resource-exploiting activities in international markets. In addition, informal institutions are typically altered over the long term (Estrin et al., 2012) and require policies to compensate for the lack of norms surrounding self-expression, desirability and performance. Government might develop active programmes with the aim of convincing more individuals to engage in international entrepreneurial activities.

This research has some limitations that offer avenues for further research. While the multilevel design in this study brings useful insights in regard to the presence of crosscountry variations in individuals' participation in international entrepreneurship, it has a cross-sectional nature. A longitudinal analysis is wanted in order to entirely take the dynamic effect of institutions into consideration. The complexities of national institutional arrangements may vary largely across different stages of country-level development. Second, the measure of internationalisation in the GEM survey represents international sales only. Future research could apply and expand the theoretical frame and logic in this paper on their international expansion and activities.

Acknowledgements

Not applicable.

Author's contributions

The author read and approved the final manuscript. 
Funding

Not applicable.

\section{Availability of data and materials}

Secondary data was secured from the following data sites: Global Entrepreneurship Monitor: https://www. gemconsortium.org/

\section{Competing interests}

The author declares that he has no competing interests.

Received: 15 May 2019 Accepted: 1 October 2019

Published online: 30 December 2019

\section{References}

Acemoglu, D., \& Johnson, S. (2005). Unbundling institutions. Journal of Political Economy, 113(5), 949-995.

Ahlstrom, D., \& Bruton, G. D. (2001). Learning from successful local private firms in China: establishing legitimacy. Academy of Management Executive, 15(4), 72-83.

Ahlstrom, D., \& Bruton, G. D. (2002). An institutional perspective on the role of culture in shaping strategic actions by technology focused entrepreneurial firms in China. Entrepreneurship Theory and Practice, 26(4), 53-69.

Ajzen, I. (1991). The theory of planned behaviour. Organizational Behaviour and Human Decision Processes, 50(2), 179-211.

Alvarez, C., Urbano, D., Coduras, A., \& Ruiz-Navarro, J. (2011). Environmental conditions and entrepreneurial activity: a regional comparison in Spain. Journal of Small Business and Enterprise Development, 18(1), 120-140.

Arenius, P., \& De Clercq, D. (2005). A network-based approach on opportunity recognition. Small Business Economics, 24(3), 249-265.

Arenius, P., \& Minniti, M. (2005). Perceptual variables and nascent entrepreneurship. Small Business Economics, 24(3), 233-247.

Autio, E. (2005). Creative tension: the significance of Ben Oviatt's and Patricia McDougall's article 'toward a theory of international new ventures'. Journal of International Business Studies, 36(1), 9-19.

Autio, E., \& Acs, Z. (2010). Intellectual property protection and the formation of entrepreneurial growth aspirations. Strategic Entrepreneurship Journal, 4(3), 234-251.

Barkema, H. G., \& Vermeulen, F. (1998). International expansion through start-up or acquisition: a learning perspective. Academy of Management Journal, 41(1), 7-26.

Bloodgood, J. M., Sapienza, H. J., \& Almeida, J. G. (1996). The internationalization of new high potential U.S. ventures: antecedents and outcomes. Entrepreneurship Theory and Practice, 20(4), 61-76.

Brouthers, K. D., Nakos, G., \& Dimitratos, P. (2015). SME entrepreneurial orientation, international performance and the moderating role of strategic alliances. Entrepreneurship Theory and Practice, 39(5), 1161-1187.

Bruton, G. D., Ahlstrom, D., \& Li, H. (2010). Institutional theory and entrepreneurship: Where are we now and where do we need to move in the future? Entrepreneurship Theory and Practice, 34, 421-440.

Bruton, G. D., Ahlstrom, D., \& Obloj, K. (2008). Entrepreneurship in emerging economies: Where are we today and where should the research go in the future. Entrepreneurship Theory and Practice, 32(1), 1-14.

Carsurd, A., \& Krueger, N. (1995). Social psychology: behavioral technology for understanding the new venture initiation processes. Advances in Entrepreneurship and Growth, 2, 73-96.

Chacar, A., \& Vissa, B. (2005). Are emerging economies less efficient? Performance persistence and the impact of business group affiliation. Strategic Management Journal, 26(10), 933-946.

Contractor, F. J., Kumar, V., \& Kundu, S. K. (2007). Nature of the relationship between international expansion and performance: the case of emerging market firms. Journal of World Business, 42(4), 401-417.

Coviello, N. E., \& McAuley, A. (1999). Internationalization and the smaller firm: a review of contemporary research. Management International Review, 39(3), 223-256.

David Urbano, Claudia Alvarez, (2014) Institutional dimensions and entrepreneurial activity: an international study. Small Business Economics 42 (4):703-716.

De Carolis, D. M., \& Saparito, P. (2006). Social capital, cognition, and entrepreneurial opportunities: a theoretical framework. Entrepreneurship Theory and Practice, 30(1), 41-56.

Dias, J., \& McDermott, J. (2006). Institutions, education, and development: the role of entrepreneurs. Journal of Development Economics, 80, 299-328.

DiMaggio, P. J., \& Powell, W. W. (1991). Introduction. In W. W. Powell \& P. J. DiMaggio (Eds.), The new institutionalism in organizational analysis (pp. 1-38). Chicago: University of Chicago Press.

Dimov, D. (2007). Opportunity insight to opportunity intention: the importance of person-situation learning match. Entrepreneurship Theory and Practice, 31(4), 561-583.

Dunkelberg, W., Moore, C., Scott, J., \& Stull, W. (2013). Do entrepreneurial goals matter? Resource allocation in new owner-managed firms. Journal of Business Venturing, 28(2), 225-240.

Estrin, S., Korosteleva, J., \& Mickiewicz, T. (2012). Which institutions encourage entrepreneurial growth aspirations? Journal of Business Venturing, 28(4), 564-580.

Etemad, H. (2004). A typology, in Dana, L-P. (Ed) Handbook of Research on International Entrepreneurship, pp. 94-125, Edward Elgar, Cheltenham.

Evald, M.R., Klyver, K. And Christensen, P.R. (2011). The effect of human capital, social capital, and perceptual values on nascent entrepreneurs' export intentions. Journal of International Entrepreneurship, 9 (1), 1-19.

Fabian, F., Molina, H., \& Labianca, G. (2009). Understanding decisions to internationalize by small and medium-sized firms located in an emerging market. Management International Review, 49, 537-563.

Filatotchev, I., Stephan, J., \& Jindra, B. (2008). Ownership structure, strategic controls and export intensity of foreign-invested firms in transition economies. Journal of International Business Studies, 39(7), 1133-1148.

Frese, M., \& Gielnik, M. M. (2014). The psychology of entrepreneurship. Annual Review of Organizational Psychology and Organizational Behavior, 1, 413-438. 
Hamilton, W. H. (1932). Institution. In E. R. A. Seligman \& A. Johnson (Eds.), Encyclopedia of the Social Sciences (Vol. 8, pp. 8489). New York: Macmillan.

Hayek, F. (1945). The use of knowledge in society. American Economic Review, 35(4), 519-530.

Hitt, M. A., Beamish, P. W., Jackson, S. E., \& Mathieu, J. E. (2007). Building theoretical and empirical bridges across levels: multilevel research in management. Academy of Management Journal, 50(6), 1385-1399.

Hitt, M. A., Uhlenbruck, K., \& Shimizu, K. (2006). The importance of resources in the internationalisation of professional service firms: the good, the bad, and the ugly. Academy of Management Journal, 49(6), 1137-1157.

Ireland, R., \& Webb, J. (2009). International entrepreneurship in emerging economies: a resource-based perspective. In A. Cooper, S. A. Alvarez, A. Carrera, L. Mesquita, \& R. Vassolo (Eds.), Entrepreneurial strategies: New technologies in emerging markets (pp. 47-69). Oxford: Blackwell.

Javidan, M., House, R. J., Dorfman, P. W., Hanges, P. J., \& Sully de Luque, M. (2006). Conceptualizing and measuring cultures and their consequences: a comparative review of GLOBE's and Hofstede's approaches. Journal of International Business Studies, 37(6), 897-914.

Khanna, T., \& Palepu, K. G. (1997). Why focused strategies may be wrong for emerging markets. Harvard Business Review, 75(4), 41-51.

King, R. G., \& Levine, R. (1993). Finance, entrepreneurship, and growth. Journal of Monetary Economics, 32, 513-542.

Kiss, A. N., Danis, W. M., \& Cavusgil, S. T. (2012). International entrepreneurship research in emerging economies: a critical review and research agenda. Journal of Business Venturing, 27(2), 266-290.

Knight, G. A., \& Cavusgil, S. T. (2004). Innovation, organisational capabilities, and the born-global firm. Journal of International Business Studies, 35(2), 124-141.

Li, T. (2018). Internationalisation and its determinants: a hierarchical approach. International Business Review, 27(4), 867-876.

Lim, D. S. K., Morse, E. A., Mitchell, R. K., \& Seawright, K. (2010). Institutional environment and entrepreneurial cognitions: a comparative business systems perspective. Entrepreneurship Theory and Practice, 34(3), 491-516.

Lim, D. S. K., Oh, C. H., \& Clercq, D. D. (2016). Engagement in entrepreneurship in emerging economies: interactive effects of individual-level factors and institutional conditions. International Business Review, 25(6), 933-945.

Locke, E. A., \& Baum, J. R. (2007). Entrepreneurial motivation. In J. R. Baum, M. Frese, \& R. A. Baron (Eds.), The psychology of entrepreneurship (pp. 93-112). Mahwah: Lawrence Erlbaum Associates Publishers.

Luis Alfonso Dau, Alvaro Cuervo-Cazurra, (2014) To formalize or not to formalize: Entrepreneurship and pro-market institutions. Journal of Business Venturing 29 (5):668-686.

Manolova, T., Eunni, R., \& Gyoshev, B. (2008). Institutional environments for entrepreneurship: evidence from emerging economies in Eastern Europe. Entrepreneurship Theory and Practice, 32(1), 203-218.

McDougall, P. P., Shane, S., \& Oviatt, B. M. (1994). Explaining the formation of international new ventures: the limits of theories from international business research. Journal of Business Venturing, 9(6), 469-487.

McGahan, A. M., \& Victer, R. (2010). How much does home country matter to corporate profitability? Journal of International Business Studies, 41, 142-165.

McMullen, J. S., \& Shepherd, D. A. (2006). Entrepreneurial action and the role of uncertainty in the theory of the entrepreneur. Academy of Management Review, 31(1), 132-152.

Minniti, M., \& Nardone, C. (2007). Being in someone else's shoes: gender and nascent entrepreneurship. Small Business Economics Journal, 28(2/3), 223-239.

Mudambi, R., \& Navarra, P. (2002). Institutions and international business: a theoretical overview. International Business Review, $11(6), 635-646$

Muralidharan, E., \& Pathak, S. (2016). Informal institutions and international entrepreneurship. International Business Review, 26(2), 288-302.

Murphy, K, Shleifer, A., \& Vishny, R. (1991). The allocation of talent: implications for growth. Quarterly Journal of Economics, 106, 503-530.

North, D. C. (1990). Institutions, institutional change and economic performance. Cambridge: Cambridge University Press.

North, D. C. (2005). Understanding the process of economic change. Princeton: Princeton University Press.

Parsons, T. (1990). Prolegomena to a theory of social institutions. American Sociological Review, 55, 318-333.

Piercy, N. F., Kaleka, A., \& Katsikeas, C. S. (1998). Sources of competitive advantage in high performing exporting companies. Journal of World Business, 33(4), 378-393.

Randolph-Seng, B., Mitchell, R. K., Vahidnia, H., Mitchell, J. R., Chen, S., \& Statzer, J. (2015). The microfoundations of entrepreneurial cognition research: toward an integrative approach. Hanover: foundations and trends ${ }^{\oplus}$ in entrepreneurship.

Reynolds, P., Bosma, N., Autio, E., Hunt, S., De Bono, N., Servais, I., et al. (2005). Global entrepreneurship monitor: data collection design and implementation 1998-2003. Small Business Economics, 24(3), 205-231.

Ryan, T. Y. (1997). Modern regression analysis. New York: John Wiley \& Sons.

Scott, W. R. (1995). Institutions and organizations. Foundations for organizational science. London: SAGE Publications.

Shane, S. (2000). Prior knowledge and the discovery of entrepreneurial opportunities. Organizational Sciences, 11(4), 448-469.

Shepherd, D. A. (2010). Multilevel entrepreneurship research: opportunities for studying entrepreneurial decision making. Journal of Management, 37, 412-420

Spence, M. (1973). Job market signaling. The Quarterly Journal of Economics, 87(3), 355-374.

Stephan, U., \& Uhlaner, L. M. (2010). Performance-based vs. socially supportive culture: a cross-national study of descriptive norms and entrepreneurship. Journal of International Business Studies, 41(8), 1347-1364.

Stephan, U., Uhlaner, L. M., \& Stride, C. (2014). Institutions and social entrepreneurship: the role of institutional voids, institutional support, and institutional configurations. Journal of International Business Studies, 46(3), 308-331.

Szyliowicz, D., \& Galvin, T. (2010). Applying broader strokes: extending institutional perspectives and agendas for international entrepreneurship research? International Business Review, 19(4), 317-332.

Tracey, P., \& Phillips, N. (2011). Entrepreneurship in emerging markets: strategies for new venture creation in uncertain institutional contexts. Management International Review, 51(1), 23-29.

Tseng, C. H., Tansuhaj, P., Hallagan, W., \& McCullough, J. (2007). Effects of firm resources on growth in multinationality. Journal of International Business Studies, 38(6), 961-974.

Veblen, T. (1914). The instinct of workmanship and the state of the industrial arts. New York: August Kelley (reprinted with a new introduction by M.G. Murphey and a 1964 introductory note by J. Dorfman, New Brunswick, Transaction Book, 1990). 
Verheul, I., Wennekers, A.R.M., Audretsch, D.B. \& Thurik, A.R. (2002). Aneclectic theory of entrepreneurship.In: Audretsch, D.B., Thurik, A.R., Verheul, I., Wennekers, A.R.M. (Eds.), Entrepreneurship: DeterminantsandPolicyinaEuropean--USComparison: 11-81.KluwerAcademicPublishers, Boston/Dordrecht.

Welter, F. (2011). Contextualizing entrepreneurship_conceptual challenges and ways forward. Entrepreneurship Theory and Practice, 35(1), 165-184.

Westhead, P. (1995). Exporting and non-exporting small firms in Great Britain. A matched pairs comparison. International Journal of Entrepreneurial Behaviour \& Research, 1(2), 6-36.

Westhead, P., Wright, M., \& Ucbasaran, D. (2001). International market selection strategies of manufacturing and services firms. Entrepreneurship and Regional Development, 13(4), 17-46.

Yeung, H. W. C. (2002). Entrepreneurship in international business: an institutional perspective? Asia Pacific Journal of Management, 19(1), 29-61.

Zahra, S. A., Korri, J. S., \& Yu, J. (2005). Cognition and international entrepreneurship: implications for research on international opportunity recognition and exploitation. International Business Review, 14(2), 129-146.

Zander, I., McDougall-Covin, P., \& Rose, E. L. (2015). Born globals and international business: evolution of a field of research. Journal of International Business Studies, 46(1), 27-35.

Zhang, X., Ma, X., Wang, Y., Li, X., \& Huo, D. (2016). What drives the internationalization of Chinese SMEs? The joint effects of international entrepreneurship characteristics, network ties, and firm ownership. International Business Review, 25(2), 522-534.

\section{Publisher's Note}

Springer Nature remains neutral with regard to jurisdictional claims in published maps and institutional affiliations.

Submit your manuscript to a SpringerOpen ${ }^{\circ}$ journal and benefit from:

- Convenient online submission

- Rigorous peer review

- Open access: articles freely available online

High visibility within the field

- Retaining the copyright to your article

Submit your next manuscript at $>$ springeropen.com 